\title{
Variation Patterns of the Blood Lipid Levels on the Sprague-Dawley-Rats Fed with Kochujang Extracts
}

\author{
${ }^{\dagger}$ Yong-Ku Woo, Tae-Hyo Kim ${ }^{*}$ and Jong-Ho Koh ${ }^{*}$ \\ Dept. of Laboratory Animal Medicine, Korea Bio-Polytechnics, Nonsan 320-905, Korea \\ *Dept. of Bio-Food Analysis, Korea Bio-Polytechnics, Nonsan 320-905, Korea
}

\section{고추장 추출물을 급여한 Sprague-Dawley-Rat에서의 혈중지질 농도의 변화 양상 '우용구 · 김태효" · 고종호"}

한국폴리텍대학 바이오캠퍼스 생명의약분석과, "한국폴리텍대학 식품분석학과

\section{국문요약}

오늘날 현대인들의 식생활방식 중 과다한 열량의 영양소 섭취로 인하여 초래되는 비만의 유발 원인 중의 하나로 알려진 고지혈증(hyperlipidemia)에 대한 예방효과가 있는 것으로 알려진 전통방식으로 제조된 고추장의 생리활성 기능성 효과를 분석하고자 하였다. 이 연구에서는 실험동물로서 Sprague-Dawley(SD)-Rat에 대해서 고추장 추출물의 건강증진 효과에 대해서 실험동물을 사용하여 직접 확인하고 시도하였다. 실험군은 실험 동물용 일반사료만을 먹인 음성대조군 그룹(N-group)과 일반사료와 고추장 추출물을 동시에 먹인 시험그룹(K-group) 그리고 양성대조군으로 고콜레스테롤 사료만을 먹인 그룹(H-group)으로 구분하여 5주간 사육하면서 건강증진효과의 발현에 대해서 분석하 였다. 3그룹의 실험동물을 5 주간의 사육 후 해부했을 때 H-group의 모든 동물 $(100 \%)$ 에서 공통적으로 심한 지방간 (fatty liver) 소견이 관찰되었으나, N-group이나 K-group의 어떠한 동물에서도 지방간 소견은 관찰되지 않았다. 한편, 실험동물의 혈장성분에 대한 혈액생화학적 성적의 비교에서는 고지혈증의 예방에 유익한 성분으로 알려진 $\mathrm{HDL}$ 의

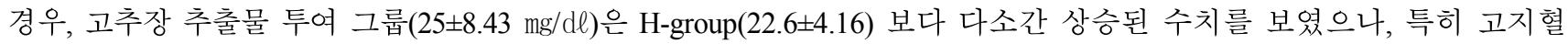
증을 악화시키는 원인으로 알려진 LDL 경우에는 H-group $(55.8 \pm 44.8 \mathrm{mg} / \mathrm{d} \ell)$ 이 고추장 추출물 투여 그룹 $(8.6 \pm 1.52$

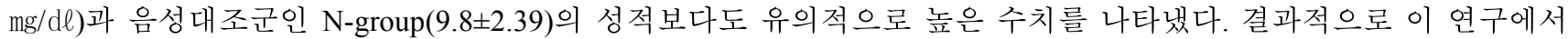
SD-Rat에 투여했던 고추장 추출물은 실험동물에서 건강기능 개선효과의 하나인 저지방혈증 효과를 발현한 것으로 사료되었다.

Key words: Kochujang, SD-rat, hypolipidemic effect, physiological activity, HDL-cholesterol

\section{Introduction}

According to recent data, the mean life expectancy of Korean people was being increased as entering into a superaged society quite rapidly in unprecedented aging speed and even the prospect on the mean life expectancy exceeds 101 years old by 2020 . This was a factual reality that Korea was one of the nations where the aging had been progressed so fast to the extent that it became very difficult to find such rapid aging phenomenon around the world (Cho et al. 2005; Ahn et al. 2006). To this end, it would not be any exaggeration if saying that the interest of Korean people in life extension and health was rising much higher than any other time or any other country. Meanwhile, owing to rather rapidly changing situation

\footnotetext{
${ }^{\dagger}$ Corresponding author: Yong-Ku Woo, Dept. of Laboratory Animal Medicine, Korea Bio-Polytechnics, Nonsan 320-905, Korea. Tel: +82-41-746-7382, Fax: +82-41-746-7310, E-mail: wooyk@snu.ac.kr
} 
of times, recently researches on identification as well as development of biologically active functional substances were vigorously undertaken for the effects of anti-aging process as well as health maintenance from Korea's traditional fermented foodderived various components (Daiana et al. 2001; Cho et al. 2007).

In fact, recent situation presented that researches were being increased more and more for the purpose to verify the functional effectiveness of food not only domestically but in overseas as well (Holvoet RA, 1996; Ha et al. 2005). As the result, many studies were being conducted for widely known anti-cancer effects as well as preventive effects on such as diabetes and atherosclerosis among positive functional effects of naturally fermented various foods so as to prevent chronic adult (regressive) diseases or lifestyle-related diseases (Kim et al. 2005; Kwon et al. 2010). Besides, according to the results from recently presented literature analyses in connection to Kochujang (Fermented Korean hot pepper paste), it was confirmed that there had been many diversified studies on the analysis for components of Kochujang, however, the studies on the actually more important core health improving effects of naturally fermented food had been relatively lacking in reality (Seo et al. 2007; Song et al. 2008). Based on above backgrounds, it was intended for this study to be performed with focus on the identification of health improving effects of Kochujang, which was one of representative traditional fermented food of Korea.

Moreover, jumping on the increased popularity of a Korea's famous dish, Bibimbap (Mixed rice with assorted vegetables and Kochujang) among foreign customers as healthy meal, as it had been served as on-board meal of domestic flights from not long ago, Kochujang as the main essential sauce added to Bibimbap attracts people's attention and interest at the same time. Kochujang was one of Korea's traditional foods, yet any pan-global promotion on it had been relatively in short to a very significant extent due to its peculiar spicy taste as well as its unusual fermentation-caused smell. Moreover, researches on the physiological effects of Kochujang were quite insufficient (Yoshioka et al. 1998; Yun et al. 2007).

Kochujang products for this study were selected among those in the market unyieldingly maintaining traditional manufacture process, based on the approaching methods of general public, and the study had attempted to identify on the health improving effects of Kochujang or its biologically active effectiveness by utilizing the animal model, SD rat to allow the best per- formance as general test in common laboratory conditions in Korea. As noted, the contemporary population's dietary was being westernized and characterized with excessive eating, intake of too much calories and with too fatty meals, we the contemporary people faced the reality that lifestyle-related diseases (obesity, diabetes, hypertension, cardiovascular diseases and etc) were increasing and progressing into serious status more and more (Ha et al. 2005; Cho et al. 2007).

In this study, tests were conducted putting the focus on hyperlipidemia as it had been investigated as the cause of health problems at the most in the contemporary population. It was because the underlying reason for it being problematic was widely known as notwithstanding hyperlipidemia was just a symptom, it could trigger not only atherosclerosis, but also if more progressed as the basis symptom and it could act as a core inductive factor that could cause myocardial infarction and even stroke at the same time, which made it as one of representative symptoms being subjected to the major concern for health management of the contemporary population (Daiana et al. 2001; Cho et al. 2007).

As one of our distinctive unique traditional foods, Kochujang was an original fermented food indispensable for Korean meal table, which was made of powder, powder mixed with powdered fermented in appropriate ratio, with addition of starchy material, malt (Kwon et al. 2010). In this study, attempts were made to confirm what kind of health function would be improved as biologically active effectiveness expressed by specific ingredients of traditional Kochujang against the reactions that had negative impacts on the health of contemporary population, by utilizing animal experiment model.

\section{Materials and Methods}

\section{Kochujang (Fermented Korean Hot Pepper Paste) Extract}

A Kochujang (Sun-Chang Glutinous Kochujang) used in this research was purchased from local groceries. A Kochujang product manufactured comparatively on the basis of the traditional methods was selected for the tests in use of glutinous rice for enrichment of the flavor among those products currently in the market, which was consisted of moisture $38.42 \%$, crude protein $4.78 \%$, crude fat $3.26 \%$, crude ash $8.04 \%$, and carbohydrate $45.75 \%$. And then the selected product was liquidated by mixing purified water with Kochujang for oral 
administration to the animal model in this study and the supernatant of the water-soluble mixture was used for administration in animal experiment.

\section{Animals}

Five-week-old male Sprague-Dawley (SD) specific pathogen free (SPF) rats (body weight $137 \pm 1 \mathrm{~g}$ ) were purchased from Orient-Bio Company (Ga-Pyung, Korea), which was internationally accredited by AAALAC (USA). On the day of purchase, only healthy ones were selected through having them quarantined, and subsequent simultaneous quarantine and acclimatization were conducted to mitigate stresses from moving and changed environment for 7 days. Meanwhile, during the 7 days of quarantine and acclimatization, those animals with healthy in appearance and no abnormality in generic symptoms were selected and assigned to 3 groups randomly by 5 heads per each group. The study was undertaken in the way that the test group (Kochujang-group; K-group) was fed with normal feed and at the same time they were orally administered with Kochujang extract. In contrary, the positive control group (High cholesterol-group; H-group) was given only with high cholesterol feed, while the negative control group (Normal-group; $\mathrm{N}$-group) was fed only with normal feed (Orient-Bio, Ga-Pyung, Korea).

\section{Breeding Conditions}

The laboratory animals were bred and managed in the breeding room exclusively produced as semi-barrier system for rats under the conditions with $22 \pm 2^{\circ} \mathrm{C}$ as set temperature, relative humidity $50 \pm 10 \%$, brightness $150 \sim 300$ Lux, 12 hours for lighting time (Lighting: 07:00 19:00), noise level as $\leq 45 \mathrm{db}$, concentration of ammonia as $\leq 20 \mathrm{ppm}$, and frequency of ventilation as 12 times/hour. For breeding cage, the cage made of polycarbonate (DaeJong, Seoul, Korea). The animals were put into cages with the stocking density of 5 heads per cage during the period for quarantine and acclimatization while the stocking density was 2 heads per cage during the test period. For bedding, litter material for laboratory animal (Aspen Shavings, Columbia, USA) was used and the cage was replaced with frequency of once a week. All instruments and beddings to be used inside the breeding room were used after autoclaving for 30 minutes at $121^{\circ} \mathrm{C}$. In particular, overall procedure related to the animal experiment was performed in compliance with the guidelines for animal experiment and standard operating procedure (SOP) after the review of the institutional animal care and use committee (IACUC) operated in the Korea Bio Polytechnics (KBP-LA1201).

\section{Feeds and Waters}

This study was performed by giving to the SD-rats radiated feeds exclusively made for laboratory animals (Orient-Bio, GaPyung, Korea) during the period for quarantine and acclimatization while special feeds and normal feeds were given to them during the test period as shown in Table 1. The special feed (D12336, Match Paigen's atherogenic Rodent diet, Research Diets Inc., New Brunswick, USA) was imported and then given to the SD-rats for 5 weeks, which were manufactured specifically by adjusting cholesterol level to $1.25 \%$ and cholic acid level to $0.5 \%$ in order to induce hyperlipidemia which would cause the obesity. The rats were given water filtered and sterilized by UV water flowing sterilizer ad libitum.

\section{Observation on General Symptoms and Deaths}

The health conditions of each rat were checked at least one time a day. During the entire period of study, all animals tested were daily observed on the profile of symptomatic variations and on any death at a certain time once a day.

Table 1. Composition of experimental diets $(\mathrm{g} / \mathrm{kg} \operatorname{diet})^{1)}$

\begin{tabular}{|c|c|c|c|}
\hline Ingredient & $\mathrm{N}_{\text {-group }}{ }^{2)}$ & H-group ${ }^{3)}$ & $K$-group ${ }^{4)}$ \\
\hline Casein & 200 & 200 & 200 \\
\hline Corn oil & 50 & 50 & 50 \\
\hline Mineral mixture (AIN-76) & 35 & 35 & 35 \\
\hline Vitamin mixture (AIN-76) & 10 & 10 & 10 \\
\hline Choline chloride & 2 & 2 & 2 \\
\hline Methionine & 3 & 3 & 3 \\
\hline Cellulose & 50 & 50 & 50 \\
\hline Sucrose & 200 & 200 & 200 \\
\hline Corn starch & 450 & 438.75 & 450 \\
\hline Cholesterol & - & 10 & - \\
\hline Taurocholic acid & - & 1.25 & - \\
\hline
\end{tabular}

1) American Institute of Nutrition (1977). Ingredients are reported on a dry weight basis.

2) Normal diet group (N-group), which was fed with normal feed only.

3) High-cholesterol diet group (H-group), which was fed with highcholesterol feed only.

4) Kochujang group (K-group), which was fed with normal feed and the liquid extracts of Kochujang. 


\section{Measurements of Body Weight and Feed Intake}

By using the electrical balance (GX-2000 EK120A, Tokyo, Japan), any change of body weight was measured at a certain time for once a week in order to observe changes in the body weights. Also, body weight was additionally measured on the day of abdominal opening. The quantity of feed taken in by the rats was confirmed and calculated when measuring the body weights every time for once a week. In particular, for the feed efficiency ratio (FER), it was calculated in accordance with the following equation presented by Eq. 1 (Ha et al. 2005).

Feed efficiency ratio $=$

Quantity of feed intake during the study period (g) / Increase of body weight during the study period (g) (Eq. 1)

\section{Body Organ Weights}

Organ weights were measured after letting all heads of rats in each group fast for 12 hours on the completion day of the study, and after taking blood samples from abdominal aorta of isoflurane (Sigma, St Louis, USA) anesthetized rats through inhalation with subsequent euthanasia in order to collect fresher and sterile blood samples. Individual organs such as heart, lungs, liver, spleen, kidneys, adrenal glands, testis, epididymis, and intestines were excised by abdominal opening and weighed using an electrical balance. In particular, for weighing the adipose tissues of male rats, the absolute weight measurement and comparison was applied to the excised peri-renal and peri-epididymal adipose tissues representatively, while the relative weights were calculated for each of all organs and tissues excised against the weights measured before abdominal opening. For the weights of organs bilaterally existing, they were calculated with the total weights measured from both side organs.

\section{Biochemical Analysis of Blood Samples}

In order to perform the biochemical analysis, the blood samples were collected from the abdominal aorta of each SD-rats anesthetized with isoflurane after abdominal opening. In especial, all plasma samples were analyzed within 4 hours after collection for the more delicate reactions. The biochemical analysis of plasma samples was performed in use of an automatic chemical analyzer (VetTest 8008, IDEXX Laboratory, USA) for various indicators including total-cholesterol (TC), triglyceride (TG), lowdensity lipoprotein cholesterol (LDL-C), high-density lipoprotein cholesterol (HDL-C), albumin, lactate dehydrogenase (LDH), total protein (TP), aspartate transaminase (AST), alanine transaminase (ALT).

\section{Statistical Analysis}

Each experiment was performed three times in duplicates. Data were analyzed using the paired $t$-test in SAS software program (Statistical Analysis System Institute Inc., Cary, N.C., USA). Multiple mean comparisons among or between the samples were carried out by Duncan's multiple range tests at $P<0.05$ $(*, * *)$ significance levels.

\section{Results and Discussion}

\section{General Symptoms and Animal Mortality}

There was no specific or abnormal symptoms observed that could be considered as the test feed-related during the study period. During the entire period of study, there was no dead rat appeared from all groups and also there was no specific clinical symptoms observed that could be recognized as the test substance-derived.

\section{Body Weight Gains and Feed Intakes}

For the weight of rats fed with Kochujang extract, the relative weight against the initial weight was increased by $54.72 \%$, with the incremental weight of $250.97 \mathrm{~g}$ in total for 5 weeks. In comparison, the weight variations in the H-group showed that the relative weight gains was increased by $68.20 \%$ in average, with the incremental weight of $215.21 \mathrm{~g}$ in total for 5 weeks. In the negative control group ( $\mathrm{N}$-group), the weight variations showed that the relative weight gains was increased by $63.09 \%$ in average with the incremental weight of $220.15 \mathrm{~g}$ in total for 5 weeks (Table 2). As the result, the weight gains of test animals (K-group) were even lower than those of the N-group, confirming that it was the lowest among the all experimental groups. Thus, it was possible to identify that the intake of Kochujang extract for 5 weeks had apparently brought the positive effects to the health improving as weight loss in rats from what above mentioned results implicate.

\section{Organ Weights}

For the weight of liver, the weight gains against its initial weight was increased by $33.95 \%$ in rats (K-group), but it only had increased by $27.11 \%$ in rats (H-group), while from rats (N-group), the liver weight was increased by $49.30 \%$. Con- 
Table 2. Effect of each diet on body weight gain, food intake, and adipose tissue weights of SD-Rats fed for 5 weeks

\begin{tabular}{lccc}
\hline \hline & N-group & K-group \\
\hline Initial body weight & $138.90 \pm 6.52$ & H-group & $137.34 \pm 1.59$ \\
Body weight gain $(\mathrm{g})$ & $220.15 \pm 8.87$ & $146.78 \pm 4.56$ & $250.97 \pm 46.5$ \\
Food intake (g) & $1,193.75 \pm 41.13$ & $215.21 \pm 17.24$ & $769.77 \pm 52.75$ \\
Feed efficiency ratio (\%) & 0.184 & $596.72 \pm 201.01$ & 0.326 \\
Tissue weight (\%, g/BW×100) & & 0.361 & \\
Peri-renal fat pad (g) & $4.33 \pm 0.019 *$ & $5.15 \pm 0.023^{* *}$ & $6.31 \pm 0.071$ \\
Epididymal fat pad (g) & $2.64 \pm 0.016^{*}$ & $1.65 \pm 0.041^{* *}$ & $3.17 \pm 0.055$ \\
\hline
\end{tabular}

1) N-group: This group was fed with normal feed only, ${ }^{2)}$ H-group: This group was fed with high-cholesterol feed only.

3) K-group: This group was fed with normal feed and the liquid extracts of Kochujang.

Different superscripts within the column indicate significantly different in the mean $\pm \mathrm{SD}(\mathrm{n}=5)$ analyzed by Duncan's multiple range test (Different superscripts within $\mathrm{N}$-group and other groups, *; H-group and $\mathrm{K}$-group, **; $p<0.05$ ).

sequently, the liver weight of the K-group was presented as specific result by showing more or less lower value than that of H-group. On the other hand, for the weight of testis, the K-group rats showed increase by $41.06 \%$ in comparison that the H-group had shown such increase by $41.77 \%$ while the N-group showed weight gains only by $40.08 \%$ as the lowest weight gain, which was quite a specific result. However, in case of epididymis, the weight gains showed by $28.63 \%$ in K-group in comparison that the H-group showed weight gains by $27.92 \%$, while the $\mathrm{N}$-group rats showed weight gains by $28.3 \%$, presented different weight gain profiles from that of testis (Table 2). For the weight of heart, K-group showed the weight gains by $44.23 \%$, the H-group showed the weight gains by $47.86 \%$, and the $\mathrm{N}$-group showed the weight gains by $47.68 \%$ respectively. Thereby, the lowest weight gain was appeared from K-group rats. In case of kidney, K-group showed the weight gains by $41.09 \%$, while weight gains were investigated as having increases in the order of the H-group (46.22\%) and the N-group (43.32\%) respectively, showing similar pattern with that of testis. When reviewed the variation of organ weight gains in comprehensive manner, liver and epididymis showed the least weight gains in K-group while spleen, kidney and other total reproductive organs showed the least weight gains in the N-group. In particular, the weight gains of liver usually suggested its profile to progress into the fatty liver symptom, therefore, the weight reduction showed more desirable results in the view of health improving function and also in case of heart, since its weight got increased as the result of peri-coronary arterial lipid accumulations, such fat weight gains became as the cause of various heart diseases as consequence (Holvoet
RA, 1996; Ha et al. 2005). From the above results, even though the weight of heart was increased with slight difference in the K-group, the effects of weight reduction in liver was interpreted as the result toward more positive direction in terms of health improving (Table 2).

\section{Weights of Peri-Renal and Peri-Epididymal Fat Tissues}

Investigation was made on the weight gains of peri-renal and peri-epididymal fat tissues in male rats for 5 weeks. From the this result, in case of K-group, the weights of peri-renal fat tissues was increased by about $7.14 \%$ against its initial weight, while the weight of the H-group was increased by $6.82 \%$, and the weights of the N-groups was increased by $8.79 \%$. In case of peri-epididymal fat tissues, it presented more prominent profile of variations as that of the K-group was increased by $13.74 \%$, while the weight of the H-group was increased by $15.49 \%$, and the weight of $\mathrm{N}$-group was increased by $13.84 \%$, which was lower gain than that of H-group. In conclusion, from above results, it showed that the hypolipidemic effect of Kochujang was expressed far more prominently from peri-epididymal fat tissues than that of peri-renal. And for the reduction of body fat gain at the internal organs of rat, the K-group showed the lowest rate of weight gains for liver, while this group showed higher increases in the weights of spleen, kidney, heart and lungs (Table 3).

\section{Blood Biochemical Analysis}

For the blood biochemical properties in male rats after 5 weeks study, between the H- and K-group showed significantly differences on the values for such as glucose, CRE, AST, AST, 
Table 3. Effect of each diet on the body organs weights in SD-Rats fed for 5 weeks

\begin{tabular}{|c|c|c|c|}
\hline Organs weights (g) & N-group ${ }^{1)}$ & H-group ${ }^{2)}$ & K-group ${ }^{3)}$ \\
\hline Liver & $12.02 \pm 0.34 *$ & $21.86 \pm 3.79$ & $23.10 \pm 3.68$ \\
\hline Spleen & $0.72 \pm 0.08$ & $0.90 \pm 0.18$ & $0.84 \pm 0.07$ \\
\hline Testis & $3.06 \pm 0.22$ & $2.94 \pm 0.25$ & $2.89 \pm 0.12$ \\
\hline Epididymis & $0.72 \pm 0.06$ & $0.73 \pm 0.12$ & $0.68 \pm 0.03$ \\
\hline Kidney & $2.79 \pm 0.13$ & $2.61 \pm 0.32$ & $2.46 \pm 0.35$ \\
\hline Heart & $1.16 \pm 0.07$ & $1.16 \pm 0.14$ & $1.22 \pm 0.10$ \\
\hline Lung & $1.42 \pm 0.07$ & $1.34 \pm 0.14$ & $1.42 \pm 0.18$ \\
\hline Adrenal glands & $0.06 \pm 0.01$ & $0.06 \pm 0.00$ & $0.06 \pm 0.01$ \\
\hline Thymus & $0.57 \pm 0.07$ & $0.68 \pm 0.16$ & $0.60 \pm 0.07$ \\
\hline Total intestines ${ }^{\mathrm{a}}$ & $26.73 \pm 2.43 *$ & $20.85 \pm 3.37$ & $20.33 \pm 1.81$ \\
\hline Total reproductive organs ${ }^{\mathrm{b}}$ & $2.05 \pm 0.21$ & $2.08 \pm 0.25$ & $1.98 \pm 0.36$ \\
\hline
\end{tabular}

a This include small and large intestines.

b This include the seminal sacs, prostate glands, urinary bladder, and vas deferens.

1) N-group: This group was fed with normal feed only.

2) H-group: This group was fed with high-cholesterol feed only.

3) K-group: This group was fed with normal feed and the liquid extracts of Kochujang.

Different superscripts within the column indicate significantly different in the mean $\pm \mathrm{SD}(\mathrm{n}=5)$ analyzed by Duncan's multiple range test (Different superscripts within N-group and other groups, *; H-group and K-group, **; $p<0.05$ ).

TP and BUN, according the statistical analysis $(p<0.05)$ (Table 4). In particular, ALT and ALP showed that high-fat feed had been hazardous or stressful factor on liver. The level of plasma total cholesterol apparently showed increase $\geq 2$ times than that of $\mathrm{N}$-group as the result of $\mathrm{K}$-group for 5 weeks. HDLcholesterol widely known as beneficial component to the body, being associated to the preventive effects of coronary arterial diseases for heart, was also known that its increase was good for health. In general, increase of HDL-cholesterol was known as facilitating the transportation of cholesterol from the blood to liver, so as to make cholesterol degraded at the liver for excretion (Kim et al. 2005; Yun et al. 2007). Thereby, according to the serum analysis results, the value of HDL-cholesterol of K-group was more reduced by $52.7 \%$ than that of N-group $(47.4 \pm 6.98 *)$, but that of H-groups was on the other hand increased by $90.4 \%(25 \pm 8.43)$ in comparison with that of K-group (22.6 \pm 4.16$)$ (Table 4). Hence, it was considered that the result enabled to identify on the hypolipidemic effects of Kochujang, which was clearly a positive effect for the health improving in vivo as proposed by others (Holvoet RA, 1996; Cho et al. 2005). Also, both of K-group and H-group presented prominent variation profiles in the values of ALT, AST as well as TP in the blood biochemical analysis, therefore, this result deemed as confirmation on the fact that a long term intake of highly fatty diet becomes quite a hazardous factor to liver. Especially, from every individual heads belonged to the H-group, there were findings of fatty liver clearly identifiable by naked eye, resulting also in finding on the weight gains of liver at the same time. Additionally, the values of AST and ALT that were being utilized most frequently and with reliability as in vivo indicators of liver damage from clinical hematological assay, and showed result with more prominent increase in the H-group. Thereby, consequently it seemed that the repetitive high-fat diet-induced fat accumulation into the liver tissues was expressed by the increased values of ALT and AST as bio-indicators of liver damage. Generally, it had been known that both values of serum AST and ALT would noticeably increase in case of acute liver cell damage in laboratory animals including rats (Holvoet RA, 1996) and especially ALT was

Table 4. Effect of each diet on the serum levels of lipids in SD-Rats fed for 5 weeks

\begin{tabular}{lccc}
\hline \multicolumn{1}{c}{ Serum levels } & N-group ${ }^{1)}$ & H-group $^{2)}$ & K-group $^{3)}$ \\
\hline Total cholesterol & $91.8 \pm 20.43$ & $190.8 \pm 148.57$ & $191.0 \pm 101.03$ \\
Triglyceride (TG) & $85.4 \pm 22.42$ & $62.8 \pm 21.86$ & $62.6 \pm 19.71$ \\
HDL-Cholesterol & $47.4 \pm 6.98^{*}$ & $22.6 \pm 4.16$ & $25 \pm 8.43$ \\
LDL-Cholesterol & $9.8 \pm 2.39$ & $55.8 \pm 44.8^{* * * *}$ & $8.6 \pm 1.52$ \\
Glucose (GLU) & $104.8 \pm 16.45$ & $85 \pm 19.68^{* *}$ & $133.4 \pm 8.96$ \\
BIL & $0.38 \pm 0.23$ & $0.44 \pm 0.05$ & $0.42 \pm 0.08$ \\
CRE & $0.18 \pm 0.04$ & $0.22 \pm 0.04 * *$ & $0.52 \pm 0.04$ \\
AST & $136.2 \pm 27.09$ & $308.4 \pm 221.87 * *$ & $134.2 \pm 4.97$ \\
ALT & $31.0 \pm 4.64$ & $81.6 \pm 95.16$ & $32.2 \pm 3.83$ \\
GGT & $2.4 \pm 1.67$ & $4.4 \pm 0.89$ & $4.2 \pm 0.84$ \\
TP & $5.9 \pm 0.32$ & $7.04 \pm 0.57^{* *}$ & $5.72 \pm 0.29$ \\
BUN & $15.58 \pm 3.29$ & $13.98 \pm 1.84^{* *}$ & $19.0 \pm 2.55$ \\
ALP & $680 \pm 105.21$ & $920.2 \pm 193.41$ & $1,332.4 \pm 279.42$ \\
\hline
\end{tabular}

1) N-group: This group was fed with normal feed only.

2) H-group: This group was fed with high-cholesterol feed only.

3) K-group: This group was fed with normal feed and the liquid extracts of Kochujang.

Different superscripts within the column indicate significantly different in the mean $\pm \mathrm{SD}$ ( $\mathrm{n}=5$ ) analyzed by Duncan's multiple range test (Different superscripts within N-group and other groups, *; H-group and K-group, **; $p<0.05$ ). 
known as relatively more specific for liver cells. According to above results, both values of AST \& ALT was increased in parallel as previously described, and especially it showed the profile of apparent increase in the value of AST. In conclusion, the present results indicated that they were commonly experiencing inflammatory processes such as chronic hepatitis due to continuous causes for a long term. On the other hand, usually the recovery time of AST activity was presented as faster than that of ALT from the blood circulation, appearing in a profile of relatively more increases compared to ALT and also AST showed higher values in various tissues such as liver, muscle and red blood cells (Daiana et al. 200; Seo et al. 2007). Thus, for the ALT values being observed as indicators to detect any acute and sub-acute liver cell damages on which the current study concentrated more, when it was more significantly increased in the H-group by $37.9 \%$ in comparison to the $\mathrm{N}$-group, this result suggested as definite result as evaluation indicator that implicates liver damage more clearly. In particular, this result was identified as consistent with the findings such as weight variation of organs as well as fatty liver lesion on the necropsy (Table 4 \& Fig. 1).

Also the noticeable rising of ALP value in particular together with GGT was analyzed as the result that strongly implicates on potential problems of cholestasis (Yoshioka et al. 1998; Yun et al. 2007). Although ALP was being influenced in rats depending on the dietary components, the increased value of GGT in particular was known as specific bio-indicator that strongly suggested cholestasis, hence, it was considered as the results manifested from every animal disclosed in this study clearly implicated strongly on expression of cholestasis induced health problems (Cho et al. 2007; Song et al. 2008). The very important fact discovered from the results of this study is that

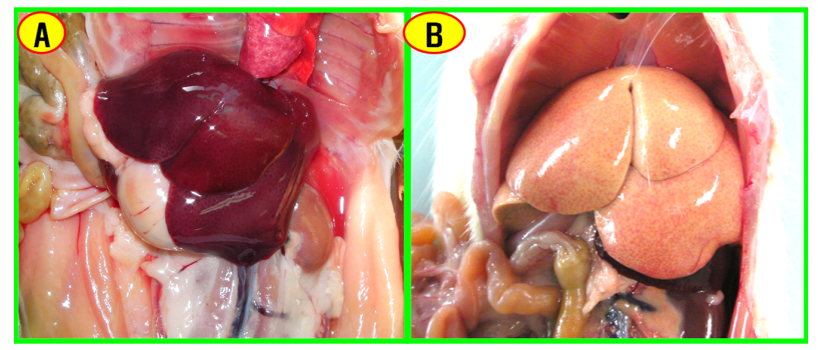

Fig. 1. Representative anatomical views of abdominal organs in SD-rats fed high cholesterol diets (H-group) (B) and Kochujang extract (K-group) (A). Note the severe fatty liver lesion (B) in SD-rats fed with high cholesterol diets (H-group), but not in the Kochujang extract group (K-group). even in case of the feeds for laboratory animals made out in the local market which had been used in this study, when keep having a long term intake (for 5 weeks), it could cause problems to the hepato-biliary system. Such fact was considered as the result implicating that more careful interest would be required for mixing of the feed ingredients by the animal feed companies, taking into account the above mentioned results for combination of ingredients while considering the results with prominent rises of GGT and ALP values were presented commonly in all of subjected animals (Table 4). In addition, it was considered that many other researchers who used the same feed with the present study should take into accounts the results presented by this study for their own result analyses.

\section{Summary}

The present study was investigated to evaluate on the health improving effect of Kochujang (Fermented Korean hot pepper paste), which was famous as Korean traditional healthy food among foreigners as it was served together with Bibimbap. For comparison, observation was made on the experimental animals (Sprague-Dawley rat) as breeding during 5 weeks, which were divided three groups as into the control groups (N-group) fed with normal feed only and high cholesterol feed only (H-group) and the K-group with combined diet of normal feed and Kochujang extracts (Water soluble complex materials). The most outstanding result was found as the definite fatty liver lesions found from all $(100 \%)$ of the rats of the H-group at the abdominal opening examination. On the other hand, there was any finding on fatty liver lesions in the N-group as well as the K-group. Therefore, it was more than enough to identify the hypolipidemic effect by visual finding only. Furthermore, from the results of blood plasma analysis from SD-rats fed with Kochujang extract (K-group), more prominent differential findings were found, the value of HDL-cholesterol, which was good for preventing the arteriosclerosis, was more or less higher than that of H-groups. But the level of LDL-cholesterol, which was one of the hazardous agents of hyperlipidemia and arteriosclerosis, was more significantly reduced to the level even lower than that of $\mathrm{N}$-group, based on the statistical analysis, in especial. According to the present results, we could find that the unidentified Korean traditional Kochujang-derived complex components had expressed both the positive health improving effects and hypolipidemic effects on the SD-rat. 


\section{References}

Ahn IS, Do MS, Kim SO. 2006. Antiobesity effect of Kochujang (Korean fermented red pepper paste) extract in 3T3-L1 adipocytes. $J$ Medicianal Food 9:15-21

Cho JH, Lee NJ, Hong SH, Kim DK, Shin SH, Park JH, Kang JK, Kim YB, Hwang SY. 2005. Effect of Hwalgidan SJ-201 on obesity induced by high-fat diet in Zucker rats. Laboratory Animal Research 21:158-163

Cho IJ, Lee C, Ha TY. 2007. Hypolipidemic effect of soluble fiber isolated from seeds of Cassia tora Linn. In rats fed a high-cholesterol diet. J Agric Food Chem 55:1592-1596

Daiana W, Kools JJ, W Robert T. 2001. Angiotensin II-induced hypertension accelerates the development of atherosclerosis in ApoE-deficient mice. Circulation 103:448-454

Ha TY, Han SY, Kim SR, Kim IH, Lee HY, Kim HK. 2005. Bioactive components in rice bran oil improve lipid profiles in rats fed a high-cholesterol diet. Nutrition Research 25:597-606

Holvoet RA. 1996. The pathogenesis of atherosclerosis. Clin Chim Acta 246:21-38

Kim SO, Kong CS, Kil JH, Kim JY, Han MS, Park KY. 2005.
Fermented wheat grain products and Kochujang inhibit the growth of AGS human gastric adenocarcinoma cells. $J$ Food Science and Nutrition 10:349-352

Kwon DY, Daily JW 3 ${ }^{\text {rd }}$, Kim HJ, Park S. 2010. Antidiabetic effects of fermented soybean products on type 2 diabetes. Nutr Res 30:1-13

Seo MY, Kim SH, Lee CH, Cha SK. 2007. Fibrinolytic, immunostimulating and cytotoxic activities of microbial strains isolated from Kochujang. Korean J Food Sci Technol 39:315-322

Song HS, Kim YM, Lee KT. 2008. Antioxidant and anticancer activities of traditional Kochujang added with garlic porridge. Journal of Life Science 18:1140-1146

Yoshioka M, Sylvie SP, Vicky D, Isabelle D. 1998. Effects of red pepper on appetite and energy intake. British Journal of Nutrition 82:115-123

Yun JW, Lee BS, Kim CW, Kim BH. 2007. Comparison with 3 high-fat diet for studying obesity in C57BL/6 mouse. Lab Anim Res 23:245-250
접 수 : 2013년
8월 20일
최종수정 : 2013년 11월 13일
채 택 : 2013년 11월 20일 